\title{
PERAN POSITIVE EMOTION DALAM MEMEDIASI PENGARUH PRODUCT KNOWLEDGE TERHADAP IMPULSE BUYING
}

\author{
Ni Putu Triana Mahadewi ${ }^{1}$ \\ Eka Sulistyawati \\ ${ }^{1,2}$ Fakultas Ekonomi dan Bisnis Universitas Udayana (Unud), Bali, Indonesia \\ email: mahadewi.triana@yahoo.com
}

\begin{abstract}
ABSTRAK
Tujuan penelitian ini adalah untuk menjelaskan pengaruh product knowledge terhadap positive emotion, untuk menjelaskan pengaruh product knowledge dan positive emotion terhadap impulse buying, serta untuk menjelaskan peran positive emotion dalam memediasi product knowledge terhadap impulse buying. Populasi dalam penelitian ini adalah konsumen produk fashion di Bali. Teknik penentuan sampel yang digunakan adalah metode purposive sampling, yakni sampel ditentukan dengan pertimbangan yaitu responden berkewarganegaan Indonesia yang berdomisili di Kota Denpasar dan Badung yang sudah pernah berbelanja produk Zara. Jumlah sampel yang digunakan dalam penelitian ini adalah sebanyak 130 responden. Teknik analisis data yang digunakan dalam penelitian ini adalah analisis jalur (Path Analysis). Hasil penelitian menunjukkan bahwa product knowledge berpengaruh positif dan signfikan terhadap positive emotion, product knowledge dan positive emotion berpengaruh positif dan signfikan terhadap impulse buying, serta positive emotion secara positif dan signifikan memediasi pengaruh product knowledge terhadap impulse buying konsumen pada produk Zara.
\end{abstract}

Kata Kunci: product knowledge, positive emotion, impulse buying

\begin{abstract}
The purpose of this study is to explain the effect of product knowledge on positive emotion, to explain the effect of product knowledge and positive emotion on impulse buying, and to explain the role of positive emotion in mediating product knowledge of impulse buying. The population in this study are consumers of fashion products in Bali. The technique of determining the sample used is purposive sampling method, namely the sample is determined by consideration, namely respondents with Indonesian citizens who are domiciled in Denpasar City and Badung who have been shopping for Zara products. The number of samples used in this study were 130 respondents. The data analysis technique used in this research is Path Analysis. The results showed that product knowledge had a positive and significant effect on positive emotion, product knowledge and positive emotion that had a positive and significant effect on impulse buying, as well as positive emotion and significantly mediated the effect of product knowledge on consumer impulse buying on Zara products.
\end{abstract}

Keywords: product knowledge, positive emotion, impulse buying 


\section{PENDAHULUAN}

Dewasa ini, kebutuhan masyarakat mengikuti perkembangan zaman, dimana perusahaan harus mampu memenuhi permintaan konsumen yang semakin hari menjadi semakin beragam. Indonesia, khususnya Provinsi Bali merupakan target potensial dalam pemasaran produk, baik dari perusahaan lokal maupun internasional. Kebutuhan yang terus menerus meningkat meyebabkan tingkat belanja konsumen ikut meningkat (Kurniawan \& Kunto, 2013). Perilaku konsumen yang sering terjadi saat ini, terutama ketika berada di dalam mall adalah impulse buying. Menurut riset, karakter konsumen di Indonesia memang cenderung tidak memiliki rencana. Hasil riset yang dilakukan oleh lembaga Frontier Consulting Group mengungkapkan bahwa proses pembelian secara impulse buying atau yang tidak direncanakan di Indonesia relatif sangat tinggi, dibandingkan dengan konsumen di Amerika Serikat. Konsumen Indonesia memiliki proses pembelian impulse sekitar 15 persen hingga 20 persen lebih tinggi (sumber: http://www.marketing.co.id/ dalam Aldhilla, 2014). Pernyataan tersebut didukung oleh hasil survei AC Nielsen mengenai perilaku pembelian konsumen di pusat pembelanjaan. Modern di tiga kota besar di Indonesia, yang dirangkum dalam Gambar 1. sebagai berikut:

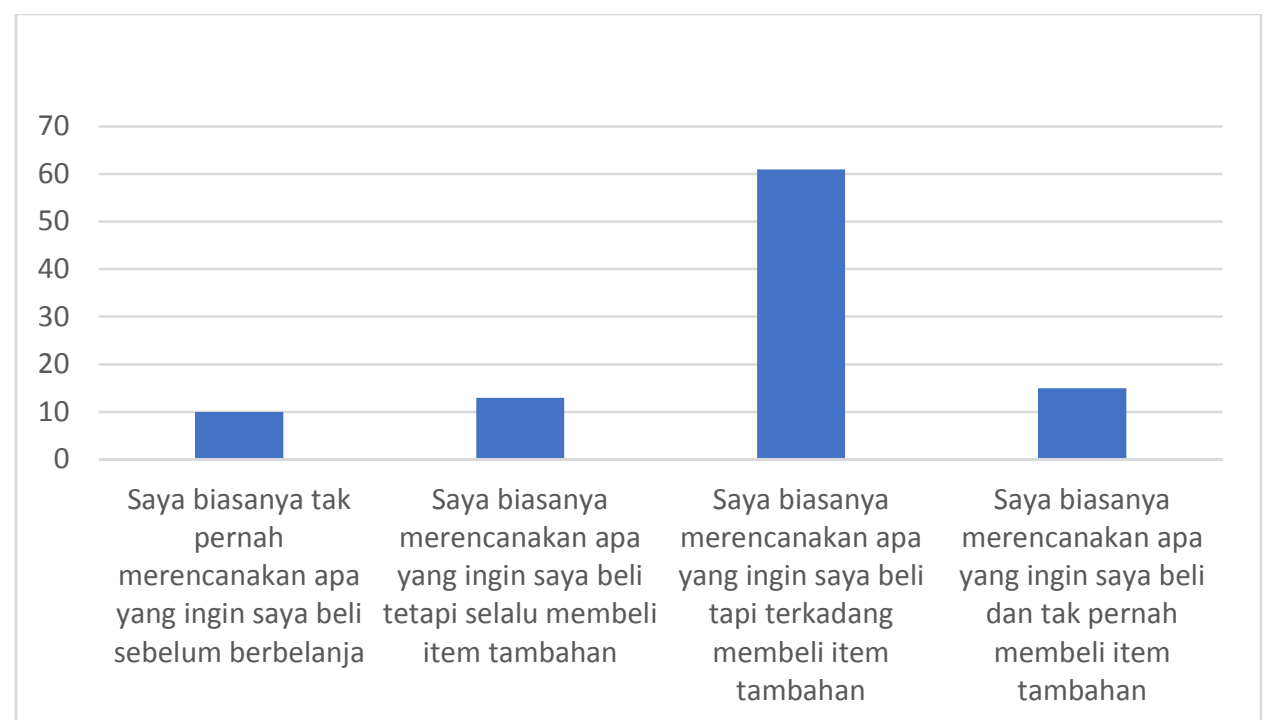

\section{Gambar 1. Perilaku Pembelian Konsumen di Pusat Pembelanjaan Modern}

Sumber: AC Nielsen, 2015

Gambar 1. menunjukkan bahwa sebagian besar konsumen di Indonesia memiliki perilaku pembelian tidak terencana ketika sedang berada di pusat pembelanjaan modern, terutama dalam membeli item tambahan yang tidak direncanakan. Dengan jumlah pusat perbelanjaan modern yang semakin banyak, diperkirakan perilaku impulse buying yang dilakukan konsumen juga akan mengalami peningkatan (Adiputra, 2015).

Perilaku impulse buying cenderung mendominasi perilaku pembelian yang dilakukan oleh konsumen pada saat ini (Naentiana \& Setiawan, 2014). Pembelian secara tiba-tiba merupakan fenomena umum di pasar dan telah menjadi titik 
fokus bagi kegiatan pemasaran (Han, Hsu, \& Sheu, 2010). Penelitian (Broden \& Soderberg, 2011) menyatakan bahwa pembelian yang tidak direncanakan bisa disebabkan karena adanya perasaan positive emotion yang menyebabkan seseorang akan melakukan impulse buying.

Semakin berkembangnya trend pakaian masa kini, fenomena impulse buying pada fashion oleh kebanyakan konsumen di beberapa department store dan distro telah sering terjadi. Beberapa stimulus yang diberikan oleh department store dan distro mendorong positive emotion (emosi positif) konsumen untuk melakukan pembelian secara tiba-tiba atau tidak terencana (Andriyanto dkk., 2016). Positive emotion dapat ditimbulkan melalui sifat afektif seseorang dan reaksi pada lingkungan yang mendukung seperti ketertarikan pada suatu produk (Rachmawati, 2009). (Japarianto \& Sugiharto, 2011) menyatakan bahwa mood seseorang yang sudah ada sebelumnya, sifat afektif, dan respon terhadap lingkungan dapat menumbuhkan emosi positif. Penciptaan emosi positif pada konsumen mengenai suatu produk atau bahkan lingkungan toko dapat meningkatkan motif konsumen dalam melakukan pembelian impulsif (Amiri, Jasour, Shirpour, \& Alizadeh, 2012)

Salah satu faktor yang dapat mempengaruhi positive emotion (emosi positif) konsumen yaitu dengan cara memperkenalkan produk agar memudahkan konsumen mengenali, dan mengingat produk tersebut (product knowledge). Pengetahuan produk akan digunakan konsumen untuk mengevaluasi berbagai alternatif yang ada kemudian menentukan satu alternatif pilihan yang dianggap akan memberi kepuasan (Ridwan et al., 2018). Menurut penelitian yang dilakukan oleh (Suwandi \& Soelasih, 2014), product knowledge berpengaruh positif dan signifikan terhadap positive emotion. (Hodgins \& Dadich, 2017) dalam penelitiannya mendapatkan hasil bahwa product knowledge berpengaruh positif dan signifikan terhadap emosi positif. Hal tersebut juga didukung oleh penelitian yang dilakukan oleh (Suwandi \& Soelasih, 2014) yang menyatakan bahwa adanya pengaruh yang signifikan antara pengetahuan konsumen terhadap emosi positif.

Terdapat perbedaan antara konsumen yang memiliki product knowledge yang tinggi dengan konsumen yang memiliki product knowledge yang rendah. Konsumen yang memiliki product knowledge yang tinggi akan memiliki perilaku impulse buying yang lebih tinggi, dibandingkan dengan konsumen yang memiliki product knowledge rendah. Oleh karena itu, semakin tinggi product knowledge yang dimiliki konsumen maka konsumen akan lebih mengenal kualitas produk tersebut, sehingga akan mampu mendorong perilaku pembelian tidak terencana yang dilakukan oleh konsumen. Hasil penelitian yang dilakukan oleh (Liang, 2012) menunjukkan bahwa pengetahuan produk berpengaruh signifikan terhadap impulse buying. Akan tetapi, penelitian yang dilakukan oleh (Suwandi \& Soelasih, 2014) menemukan hasil bahwa product knowledge tidak berpengaruh signifikan terhadap impulse buying, dimana hal tersebut menunjukkan bahwa pengetahuan produk belum tentu menyebabkan terjadinya pembelian secara tiba-tiba.

Perilaku impulse buying ini sering dijumpai di mall, khususnya pada produk fashion. Hal tersebut didukung oleh hasil survei Google Indonesia yang menempatkan fashion sebagai produk paling banyak dibeli oleh konsumen. Pernyataan serupa juga disampaikan oleh Gati Wibawaningsih, 
Direktur Jenderal Industri Kecil dan Menengah Kementerian Perindustrian Republik Indonesia yang mengatakan ekspor produk fashion Indonesia setiap tahun terus meningkat. Pada Tahun 2017 ekspor meningkat 8,7 persen dengan nilai US\$13,29 miliar dan menyumbang PDB sebesar 3,76 persen. Ini menunjukkan industri fashion Indonesia memiliki daya saing di luar negeri. Tingginya tingkat pembelian konsumen pada produk fashion dapat dilihat dari Gambar 1.2 sebagai berikut:

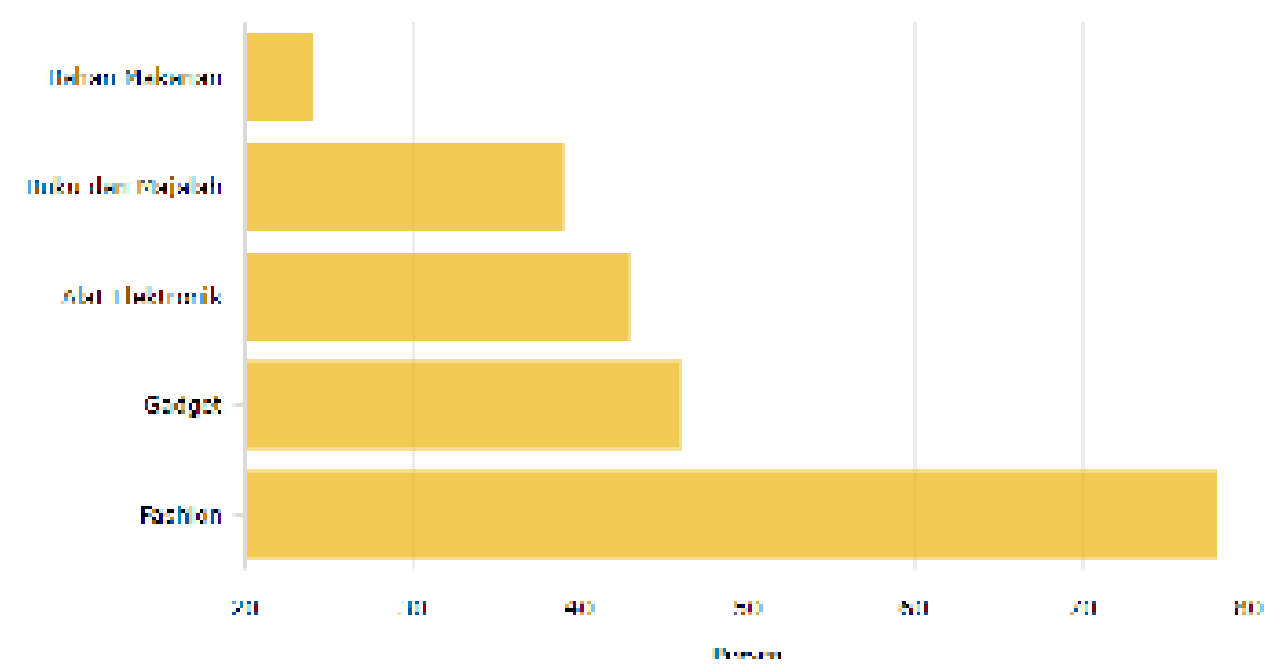

Gambar 2. Produk yang paling sering dibeli konsumen

Berdasarkan Gambar 2. dapat diketahui bahwa sebanyak 78 persen responden cenderung melakukan pembelian produk fashion dibandingkan produk lainnya. Semakin banyaknya minat konsumen pada produk fashion, menyebabkan industri fashion semakin berkembang dan saling bersaing untuk menawarkan produk yang berkualitas. Dalam hal ini informasi yang diperoleh oleh konsumen mengenai produk fashion akan menjadi evaluasi bagi konsumen untuk memilih produk yang terbaik. Pemahaman dan pengetahuan konsumen akan produk sangat penting karena pengetahuan merupakan dasar keputusan perilaku konsumen dan nantinya akan berpengaruh pada positive emotion konsumen dan impulse buying.

Berdasarkan fenomena perkembangan bisnis fashion dan banyaknya perilaku impulse buying pada konsumen di Indonesia, maka penelitian ini berupaya untuk menjelaskan secara lebih dalam perihal tentang positive emotion memediasi product knowledge terhadap impulse buying. Variabel $\mathrm{X}$ pada penelitian ini adalah product knowledge, variabel $\mathrm{Y}_{1}$ adalah positive emotion dan variabel $\mathrm{Y}_{2}$ adalah impulse buying.

Konsep utama dalam Theory of Reasoned Action (TRA) adalah sebagai motivasi individu dalam keputusan untuk mengerahkan upaya dalam melakukan perilaku tertentu. Menurut Theory of Reasoned Action, sebagian besar perilaku manusia dapat diprediksi berdasarkan niat karena perilaku, seperti kehendak. Artinya, dalam proses keputusan, seseorang memiliki tingkat kontrol kehendak yang tinggi, dengan demikian, dapat membuat pilihan yang beralasan diantara 
beberapa alternatif. Oleh karena sifatnya sebagai daya prediksi yang kuat, Theory of Reasoned Action telah banyak digunakan sebagai model untuk memprediksi niat dan perilaku di bidang pemasaran dan perilaku konsumen. Menurut Theory of Reasoned Action, niat perilaku adalah fungsi dari dua faktor, yaitu sikap terhadap perilaku dan norma subjektif.

Sikap mempengaruhi perilaku lewat suatu proses pengambilan keputusan yang teliti dan beralasan dan dampaknya terbatas hanya pada tiga hal; Pertama, perilaku tidak banyak ditentukan oleh sikap umum tapi oleh sikap yang spesifik terhadap sesuatu. Kedua, perilaku dipengaruhi tidak hanya oleh sikap tapi juga oleh norma-norma subjektif (subjective norms) yaitu keyakinan kita mengenai apa yang orang lain inginkan agar kita perbuat. Ketiga, sikap terhadap suatu perilaku bersama norma-norma subjektif membentuk suatu intensi atau niat berperilaku tertentu.

Product knowledge (pengetahuan produk) memiliki peran yang penting dalam meneliti tentang perilaku pembelian suatu produk. Konsumen perlu mengetahui karakteristik suatu produk. Apabila konsumen kurang memahami informasi tentang karakteristik suatu produk, konsumen bisa salah mengambil keputusan membeli. Product knowledge adalah kumpulan berbagai informasi mengenai suatu produk. Pengetahuan ini meliputi kategori produk, merek, terminologi produk, atribut atau fitur produk, harga produk dan kepercayaan terhadap produk. Konsumen memiliki pengetahuan tentang produk yang berbedabeda, ada yang mencari tahu info dengan datang langsung ke sumbernya, dan ada pula yang mencari tahu info dari sekitarnya.

Emosi adalah sebuah efek dari mood yang merupakan faktor penting konsumen dalam keputusan pembelian. Faktor perasaan atau emosi merupakan konstruk yang bersifat temporer karena berkaitan dengan situasi atau objek tertentu. Emosi positif dapat didatangkan dari sebelum terjadinya mood seseorang, kecondongan sifat afektif seseorang dan reaksi pada lingkungan yang mendukung seperti ketertarikan pada item barang ataupun adanya promosi penjualan (Rachmawati, 2009). Faktor perasaan atau emosi merupakan konstruk yang bersifat temporer karena berkaitan dengan situasi atau objek tertentu. Emosi juga dapat mempengaruhi suasana hati dan merupakan faktor penting dalam pengambilan keputusan konsumen. Suasana hati individu yang sudah ada sebelumnya, sifat afektif, dan reaksi terhadap pertemuan arus lingkungan dapat menimbulkan positive emotion.

Konsumen sebelum melakukan pembelian cenderung mulai dengan mengumpulkan informasi produk berdasarkan pengalaman pribadi dan eksternal lingkungan. Ketika jumlah informasi mencapai tingkat tertentu, yaitu konsumen memiliki pengetahuan produk yang baik, maka konsumen akan memulai penilaian dan proses evaluasi, serta membuat keputusan pembelian setelah perbandingan dan penilaian. Apabila konsumen memahami bahwa suatu produk memiliki kualitas yang tinggi, maka konsumen akan memutuskan melakukan pembelian tanpa pikir panjang.

Menurut penelitian yang dilakukan oleh (Suwandi \& Soelasih, 2014), product knowledge berpengaruh positif dan signifikan terhadap positive emotion. (Hodgins \& Dadich, 2017) dalam penelitiannya mendapatkan hasil bahwa product 
knowledge berpengaruh positif dan signifikan terhadap emosi positif. Hal tersebut juga didukung oleh penelitian yang dilakukan oleh (Suwandi \& Soelasih, 2014) yang menyatakan bahwa adanya pengaruh yang signifikan antara pengetahuan konsumen terhadap emosi positif.

Berdasarkan pernyataan dan hasil penelitian tersebut, maka dapat di tarik hipotesis sebagai berikut.

$\mathrm{H}_{1}$ : Product knowledge berpengaruh positif signifikan terhadap positive emotion

Product knowledge adalah cakupan seluruh informasi akurat yang disimpan dalam memori konsumen yang sama baiknya dengan persepsinya terhadap pengetahuan produk (Ridwan et al., 2018). Terdapat perbedaan antara konsumen yang memiliki product knowledge yang tinggi dengan konsumen yang memiliki product knowledge yang rendah. Konsumen yang memiliki product knowledge yang tinggi akan memiliki perilaku impulse buying yang lebih tinggi, dibandingkan dengan konsumen yang memiliki product knowledge rendah. Oleh karena itu, semakin tinggi product knowledge yang dimiliki konsumen maka konsumen akan lebih mengenal kualitas produk tersebut, sehingga akan mampu mendorong perilaku pembelian tidak terencana yang dilakukan oleh konsumen.

Berdasarkan penelitian yang dilakukan oleh (Liang, 2012) terdapat pengaruh yang signifikan antara pengetahuan produk konsumen terhadap pembelian tanpa direncanakan. Penelitian (Juanita, 2010) juga menunjukkan adanya pengaruh yang signifikan dan positif antara pengetahuan produk terhadap impulse buying. Selanjutnya dalam penelitian (Deviana \& Giantari, 2016) menunjukkan bahwa product knowledge berpengaruh positif terhadap impulse buying konsumen.

Berdasarkan pernyataan dan hasil penelitian tersebut, maka dapat di tarik hipotesis sebagai berikut.

$\mathrm{H}_{2}$ : Product knowledge berpengaruh positif signifikan terhadap impulse buying.

Emosi positif menyebabkan konsumen seolah-olah memiliki lebih banyak kebebasan untuk bertindak dan akan terus membentuk perilaku yang bertujuan untuk mempertahankan keadaan emosi positif tersebut. Emosi secara kuat mempengaruhi tindakan pembelian tidak terencana. Konsumen yang dalam keadaan emosi positif cenderung mengurangi kompleksitas pengambilan keputusan dan cepatdalam mengambil keputusan pembelian. Dibandingkan dengan emosi negatif, konsumen dalam keadaan emosi positif memperlihatkan perilaku pembelian tidak terencana yang lebih besar karena timbul perasaan yang bebas, keinginan untuk menghargai diri, dan tingkat energi yang tinggi untuk melakukan pembelian (Adiputra, 2015).

(Park \& Lennon, 2006) menyatakan bahwa emosi merupakan sebuah efek dari mood yang merupakan faktor penting konsumen dalam keputusan pembelian. (Budiharta \& Santika, 2015) dalam penelitiannya mendapatkan hasil bahwa emosi positif berpengaruh positif dan signifikan terhadap pembelian impulsif. ( $\mathrm{Xu}$, 2007) menyatakan bahwa semakin positif luapan perasaan yang dirasa konsumen akan mendorong konsumen untuk melakukan tindakan impulsif. (Anggoro, 2013) menemukan bahwa emosi positif berpengaruh positif dan signifikan terhadap pembelian impulsif, yang artinya bahwa semakin positif perasaan konsumen saat 
melakukan interaksi di dalam gerai, maka kecenderungan konsumen untuk melakukan pembelian impulsif juga semakin besar. Emosi positif yang dirasakan konsumen dapat mempengaruhi pembelian (Naentiana \& Setiawan, 2014).

Berdasarkan pernyataan dan hasil penelitian tersebut, maka dapat di tarik hipotesis sebagai berikut.

$\mathrm{H}_{3}$ : Positive emotion berpengaruh positif signifikan terhadap impulse buying.

Menurut penelitian (Hodgins \& Dadich, 2017) dalam penelitiannya mendapatkan hasil bahwa product knowledge berpengaruh positif dan signifikan terhadap emosi positif. (Juanita, 2010) menunjukkan adanya pengaruh yang signifikan dan positif antara pengetahuan produk terhadap impulse buying. (Anggoro, 2013) menemukan bahwa emosi positif berpengaruh positif dan signifikan terhadap pembelian impulsif, yang artinya bahwa semakin positif perasaan konsumen saat melakukan interaksi di dalam gerai, maka kecenderungan konsumen untuk melakukan pembelian impulsif juga semakin besar. Emosi positif yang dirasakan konsumen dapat mempengaruhi pembelian (Naentiana \& Setiawan, 2014).

Berdasarkan pernyataan dan hasil penelitian tersebut, maka dapat di tarik hipotesis sebagai berikut.

$\mathrm{H}_{4}$ : Positive emotion memediasi pengaruh product knowledge terhadap impulse buying.

\section{METODE PENELITIAN}

Lokasi penelitian merupakan suatu tempat atau wilayah dimana penelitian tersebut akan di laksanakan. Penelitian ini dilaksanakan di Bali. Alasan Bali sebagai lokasi penelitian ini karena masyarakat Bali memiliki tingkat pendapatan yang tinggi dan didukung dengan daya beli yang cukup tinggi. Obyek dalam penelitian ini adalah perilaku impulse buying konsumen, positive emotion dan product knowledge. Pada penelitian ini penulis menggunakan konsumen Zara Beachwalk Kuta Bali karena produk Zara memiliki kualitas baik dimata konsumen dan produk yang ditawarkan Zara sangat beragam, mulai dari baju, celana, aksesoris, parfum, ikat pinggang, tas, sepatu, sandal yang nantinya akan menyebabkan terjadinya impulse buying.

Pada penelitian ini terdapat tiga variabel yang dikaji, variabel-variabel tersebut adalah variabel eksogen yaitu product knowledge (X) dan variabel endogen yaitu Positive Emotion dan ( $\left.\mathrm{Y}_{1}\right)$ Impulse buying $\left(\mathrm{Y}_{2}\right)$.

Populasi dalam penelitian ini adalah konsumen produk fashion di Bali, yang jumlahnya tidak diketahui secara pasti. Dalam penelitian ini, metode penentuan sampel yang digunakan yaitu non-probability sampling yaitu teknik pengambilan sampel yang tidak memberi peluang atau kesempatan yang sama bagi setiap unsur atau anggota populasi untuk dipilih menjadi sampel. Agar mendapatkan data yang valid, maka jumlah sampel responden yang diambil dan ditentukan paling sedikit 5-10 kali jumlah indikator (Ferdinand, 2002:47). Dimana, jumlah indikator pada penelitian ini adalah sebanyak 13, sehingga jumlah dari sampel responden adalah : 13 indikator $\mathrm{x} 10$ responden $=130$ responden . 
Tabel 1.

Kisi-Kisi Instrumen Penelitian

\begin{tabular}{cll}
\hline Variabel & \multicolumn{1}{c}{ Indikator } & Refrensi \\
\hline Eksogen & & Fajar Raja \\
Product & $\mathrm{X}_{1}$. Memiliki pengetahuan tentang produk & $(2015)$ \\
knowledge & $\mathrm{X}_{2}$. Mengingat pengetahuan atas produk & \\
$(\mathrm{X})$ & $\mathrm{X}_{3}$. Pengalaman sebelumnya dari penggunaan & \\
Endogen & & \\
Positive & $\mathrm{Y}_{1.1}$. Merasa bersemangat & Amiri et al. \\
Emotion & $\mathrm{Y}_{1.2}$. Merasa puas & 2012 \\
$\left(\mathrm{Y}_{1}\right)$ & $\mathrm{Y}_{1.3}$. Merasa senang & \\
& $\mathrm{Y}_{1.4}$ Penuh dengan emosi & \\
Endogen & & Deviana dan \\
Impulse & $\mathrm{Y}_{2.1 .}$ Tanggapan atas tawaran diskon & Giantari,2016) \\
Buying & $\mathrm{Y}_{2.2 .}$ Pembelian pakian model terbaru & \\
$\left(\mathrm{Y}_{2}\right)$ & $\mathrm{Y}_{2.3 .}$ Pembelian dilakukan secara tiba-tiba & \\
& $\mathrm{Y}_{2.4 .}$ Selalu melakukan pembelian produk & \\
& $\mathrm{Y}_{2.5}$ Terobsesi untuk membelanjakan seluruh uang & \\
\hline Sumber: Data diolah, 2018 & $\mathrm{Y}_{2.6}$ Membeli produk fashion yang tidak terlalu di butuhkan &
\end{tabular}

Teknik analisis yang digunakan dalam penelitian ini adalah teknik analisis jalur (path analysis). Berikut persamaan regresi dalam penelitian ini:

Persamaan Sub-struktural 1

$$
\mathrm{Y}_{1}=\beta_{1} \mathrm{X}+\mathrm{e}
$$

Persamaan Sub-struktural 2

$$
\begin{array}{ll}
\mathrm{Y}_{2}=\beta_{1} \mathrm{X}+\beta_{3} \mathrm{Y}_{1} & +\mathrm{e}_{2} \\
\text { Keterangan: } & \\
\mathrm{X} & =\text { product knowledge } \\
\mathrm{Y}_{1} & =\text { positive emotion } \\
\mathrm{Y}_{2} & =\text { impulse buying } \\
\beta_{1} \beta_{2} \beta_{3} & =\text { koefisien regresi variabel } \\
\mathrm{e} & =\text { error }
\end{array}
$$

\section{HASIL DAN PEMBAHASAN}

Zara adalah salah satu merek yang berasal dari Spanyol dan bermarkas di Arteixo, Gallicia. Zara didirikan pada tahun 1975 oleh Armancio Ortega dan Rosallia mera. Zara sendiri merupakan flagship store dari Inditex, yang juga memiliki beberapa merek ternama lainnya seperti :Massimo Dutti, Pull and Bear, Oysho, Uterqüe, Stradivarius dan Bershka.

Zara sendiri hanya membutuhkan waktu kurang lebih 2 minggu untuk mengembangkan produk-produk barunya dan meluncurkan sekitar 10.000 design baru setiap tahunnya. Armancio ortega pertama kali membuka Zara Store di sebuah jalan utama di pusat kota A Coruña, Galicia, Spanyol. Toko tersebut ternyata cukup sukses, sehingga Armancio membuka beberapa store lagi di Spanyol. Selama tahun 1980, Ortega mulai mengubah desain, manufaktur dan proses distribusi untuk mengurangi lead time dan bereaksi terhadap tren baru 
dalam cara yang lebih cepat, dalam apa yang ia sebut "mode instan". Pada tahun 1980, perusahaan mulai melakukan ekspansi internasional melalui Porto , Portugal. Pada tahun 1989 mereka memasuki Amerika Serikat dan Perancis pada tahun 1990. Dan hingga saat ini, Zara sudah terdapat di 73 negara di Dunia termasuk di Indonesia. Zara memiliki beberapa jenis pakaian, mulai dari Wanita (Woman dan TRF), Pria (Men), anak-anak (Zara Kids), Zara Home hingga kosmetik. Store Zara paling banyak berada di Spanyol (329 toko), dan Prancis (114 Toko). Sementara di Indonesia, Zara hanya ada 13 toko. Louis Vuitton Fashion Director Daniel Piette mendeskripsikan Zara sebagai "retailer yang paling inofatif dan sangat efektif di dunia ini." Oleh CNN, Zara juga disebut sebut sebagai "Spanish success story."

Zara masuk pertama kali ke Indonesia pada tanggal 18 Agustus 2005. Perjalanan Zara di Indonesia tidak lepas dari usaha PT. Mitra Adi Perkasa Tbk. (MAP) dalam meyakinkan pihak Inditex untuk membuka gerainya di Indonesia. MAP menginginkan untuk dapat memiliki hak eksklusif Zara sejak tahun 1999, namun karena alasan ketidakstabilan kondisi di Indonesia ketika itu maka Inditex baru memberikan hak kepada MAP untuk membuka jaringan gerai Zara di Indonesia pada tahun 2005. Setelah masuk kebeberapa pusat perbelanjaan yang ada di Jakarta, Zara juga membuka toko di luar kota salah satunya di kota Bandung tepatnya pada tahun 2010 Zara membuka toko dipusat perbelanjaan yang ada di kota Bandung yaitu Mall Paris Van Java.

MAP merupakan perusahaan yang mendistribusikan produk fashion, produk olahraga dan gaya hidup. Saat ini MAP mengoperasikan lebih dari 500 gerai di 22 kota besar di Indonesia. Portofolio lisensi merek yang dipegang sangat beragam, mulai dari department store, ritel peralatan dan perlengkapan olahraga, produk fashion, kids store, books store, health and beauty spot, food and beverage retail dan home and furnishing store. Beberapa konsep ritel MAP yang terkenal adalah Sogo, Debenhams, Marks and Spencer, Starbucks, Next, Kidz Station, Planet Sports, Sports Station, Golf House dan Kinokuniya. Selain mengolah gerai-gerai ritel, MAP juga menjadi distributor untuk sejumlah merek Internasional terkemuka seperti Reebok, Nine West, Mizuno, Speedo dan Converse. Untuk produk Zara, MAP mendatangkan langsung dari Spanyol dengan model pembelian sistem putus, yang artinya jika ada produk Zara yang tidak terjual maka hal tersebut menjadi resiko bisnis yang harus ditanggung oleh MAP. Keberadaan Zara sendiri di Indonesia menjadi fenomenal bagi MAP, karena ditahun awal keberadaannya Zara telah mendapat sambutan antusias pasar fashion Indonesia. Sehingga keberadaan Zara dapat memberikan keuntungan besar bagi MAP.

Selain itu, merek fashion asal Spanyol ini juga memberikan pengaruh positif melalui gerai dan produknya yang eksklusif kepada citra perusahaan MAP sebagai perusahaan jaringan ritel dan distributor merek-merek global di Indonesia.

Berikut data identitas responden berdasarkan jenis kelamin, usia, jenjang pendidikan terakhir dan pekerjaan responden. Secara rinci karakteristik responden disajikan pada Tabel 2. 
Tabel 2.

Karakteristik Responden Penelitian

\begin{tabular}{|c|c|c|c|c|}
\hline No & Karakteristik & Klasifikasi & $\begin{array}{c}\text { Jumlah } \\
\text { Responden } \\
\text { (orang) }\end{array}$ & $\begin{array}{c}\text { Presentase } \\
\text { Responden } \\
\text { (\%) }\end{array}$ \\
\hline \multirow{2}{*}{1} & \multirow{2}{*}{ Jenis Kelamin } & Laki-Laki & 43 & 33,08 \\
\hline & & Perempuan & 87 & 66,92 \\
\hline & \multicolumn{2}{|c|}{ Jumlah } & 130 & 100 \\
\hline & & 18-23 Tahun & 71 & 54,62 \\
\hline & & 24-29 Tahun & 22 & 16,92 \\
\hline \multirow{4}{*}{2} & Usia & 30-35 Tahun & 13 & 10,00 \\
\hline & & 36-41 Tahun & 14 & 10,77 \\
\hline & \multirow{2}{*}{\multicolumn{2}{|c|}{$\geq 42$ Tahun }} & 10 & 7,69 \\
\hline & & & 130 & 100 \\
\hline \multirow[t]{7}{*}{3} & Pendidikan & SMA & 66 & 50,77 \\
\hline & Terakhir & Diploma & 17 & 13,08 \\
\hline & & Sarjana & 27 & 20,77 \\
\hline & & Pasca Sarjana & 20 & 15,38 \\
\hline & & & 130 & 100 \\
\hline & & Pegawai Negeri/ABRI & 13 & 10,00 \\
\hline & & Pegawai Swasta & 22 & 16,92 \\
\hline \multirow{4}{*}{4} & Pekerjaan & Wiraswasta & 18 & 13,85 \\
\hline & & Pelajar/Mahasiswa & 63 & 48,46 \\
\hline & & Ibu Rumah Tangga & 14 & 10,77 \\
\hline & \multicolumn{2}{|c|}{ Jumlah } & 130 & 100 \\
\hline
\end{tabular}

Sumber: Data diolah, 2018

Tabel 2. menunjukkan bahwa sebagian besar responden yang pernah melakukan pembelian tidak terencana pada produk Zara berasal dari berbagai macam usia, pekerjaan, dan pendidikan terakhir. Berdasarkan kriteria jenis kelamin menunjukkan bahwa responden yang berjenis kelamin perempuan sebanyak 87 orang atau 66,92 persen, sedangkan responden laki-laki sebanyak 43 orang atau 33,08. Hal ini menunjukkan bahwa responden dalam penelitian ini yang pernah melakukan pembelian tidak terencana pada produk Zara mayoritas adalah konsumen perempuan.

Apabila ditinjau berdasarkan usia responden, data menunjukkan bahwa responden yang berusia 18-23 tahun sebanyak 71 orang atau 54,62 persen, responden yang berusia 24-29 tahun sebanyak 22 orang atau 16,92 persen, responden yang berusia 30-35 tahun sebanyak 13 orang atau 10 persen, dan responden yang berusia lebih dari 42 tahun sebanyak 10 orang atau 7,69 persen. Hal ini menunjukkan bahwa responden yang pernah melakukan pembelian tidak terencana pada produk Zara berasal dari berbagai rentang usia, namun dalam penelitian ini mayoritas responden yang memiliki impulse buying pada produk Zara adalah yang berusia 18 hingga 23 tahun.

Pengelompokkan berdasarkan jenjang pendidikan terakhir menunjukkan bahwa responden dengan jenjang pendidikan akhir SMA sebanyak 66 orang atau 50,77 persen, responden dengan jenjang pendidikan diploma sebanyak 17 orang atau 13,08 persen, Sarjana sebanyak 27 orang atau 20,77 persen dan responden yang memiliki jenjang pendidikan akhir Pasca Sajana sebanyak 20 orang atau 15,38 persen. Hal ini mengindikasikan bahwa responden dengan 
jenjang pendidikan akhir SMA yang lebih dominan memiliki perilaku impulse buying pada produk Zara.

Apabila ditinjau berdasarkan pekerjaan responden, maka menunjukkan responden yang bekerja sebagai pegawai negeri/ABRI sebanyak 13 orang, pegawai swasta sebanyak 22 orang atau 16,92 persen, wiraswasta sebanyak 18 orang atau 13,85, pelajar atau mahasiswa sebanyak 63 orang atau 48,46 persen dan ibu rumah tangga sebanyak 14 orang atau 10,77 persen. Hal ini memberikan informasi bahwa mayoritas responden dalam penelitian ini yang pernah melakukan pembelian tidak terencana pada produk Zara adalah pelajar atau mahasiswa.

Suatu instrumen dikatakan valid apabila memiliki koefisien korelasi antara butir dengan skor total dalam instrumen tersebut lebih besar dari 0,30 dengan tingkat kesalahan Alpha 0,05. Tabel 3. berikut menyajikan hasil uji validitas instrumen penelitian.

Tabel 3.

Rekapitulasi Hasil Uji Validitas Instrumen Penelitian

\begin{tabular}{ccccc}
\hline \multirow{2}{*}{ Variabel } & Indikator & $\begin{array}{c}\text { Koefisien } \\
\text { Korelasi }\end{array}$ & $\begin{array}{c}\text { Sig. (2- } \\
\text { tailed) }\end{array}$ & Keterangan \\
\hline \multirow{3}{*}{ Product knowledge (X) } & $\mathrm{X}_{1}$ & 0,920 & 0,000 & Valid \\
& $\mathrm{X}_{2}$ & 0,926 & 0,000 & Valid \\
& $\mathrm{X}_{3}$ & 0,865 & 0,000 & Valid \\
\multirow{3}{*}{ Positive emotion (M) } & $\mathrm{Y}_{1.1}$ & 0,878 & 0,000 & Valid \\
& $\mathrm{Y}_{1.2}$ & 0,747 & 0,000 & Valid \\
& $\mathrm{Y}_{1.3}$ & 0,884 & 0,000 & Valid \\
& $\mathrm{Y}_{1.4}$ & 0,750 & 0,000 & Valid \\
& $\mathrm{Y}_{2.1}$ & 0,627 & 0,000 & Valid \\
& $\mathrm{Y}_{2.2}$ & 0,839 & 0,000 & Valid \\
& $\mathrm{Y}_{2.3}$ & 0,596 & 0,000 & Valid \\
& $\mathrm{Y}_{2.4}$ & 0,627 & 0,000 & Valid \\
& $\mathrm{Y}_{2.5}$ & 0,844 & 0,000 & Valid \\
& $\mathrm{Y}_{2.6}$ & 0,611 & 0,000 & Valid \\
\hline
\end{tabular}

Sumber : Data diolah, 2018

Hasil uji validitas pada Tabel 3. menunjukkan bahwa seluruh instrumen penelitian yang digunakan untuk mengukur variabel product knowledge, positive emotion dan impulse buying memiliki nilai koefisien korelasi dengan skor total seluruh item pernyataan lebih besar dari 0,30 dengan signifikansi kurang dari 0,05 . Hal ini menunjukkan bahwa butir-butir pernyataan dalam instrument penelitian tersebut valid dan layak digunakan sebagai instrument penelitian.

Nilai Alpha Cronbach dinyatakan reliabel jika nilainya lebih besar atau sama dengan 0,60. Rekapitulasi hasil uji reliabilitas instrumen penelitian dapat dilihat pada Tabel 4 . berikut.

Tabel 4.

Rekapitulasi Hasil Uji Reliabilitas Instrumen Penelitian

\begin{tabular}{cccc}
\hline No. & Variabel & Cronbach's Alpha & Keterangan \\
\hline $\mathbf{1}$ & Product knowledge $(\mathrm{X})$ & 0,944 & Reliabel \\
$\mathbf{2}$ & Positive emotion $\left(\mathrm{Y}_{1}\right)$ & 0,894 & Reliabel \\
$\mathbf{3}$ & Impulse buying $\left(\mathrm{Y}_{2}\right)$ & 0,842 & Reliabel \\
\hline
\end{tabular}

Sumber : Data diolah, 2018 
Hasil uji reliabilitas yang disajikan dalam Tabel 4 menunjukkan bahwa seluruh instrumen penelitian memiliki koefisien Cronbach's Alpha lebih dari 0,60. Jadi dapat dinyatakan bahwa seluruh variabel telah memenuhi syarat reliabilitas atau kehandalan sehingga dapat digunakan untuk melakukan penelitian.

Apabila koefisien Asymp. Sig. (2-tailed) lebih besar dari 0,05 maka data tersebut dikatakan berdistribusi normal.

Tabel 5.

Hasil Uji Normalitas Struktur 1

\begin{tabular}{lc}
\hline & Unstandardized Residual \\
\hline $\mathrm{N}$ & 130 \\
Kolmogorov-Smirnov $Z$ & 0,686 \\
Asymp.Sig.(2-tailed) & 0,734 \\
\hline Sumber & Data (1)ah 2018 \\
\hline
\end{tabular}

Sumber : Data diolah, 2018

Berdasarkan Tabel 5. dapat dilihat bahwa nilai Kolmogorov Sminarnov (KS) sebesar 0,686, sedangkan nilai Asymp. Sig. (2-tailed) sebesar 0,734. Hasil tersebut mengindikasikan bahwa model persamaan regresi tersebut berdistribusi normal karena nilai Asymp. Sig. (2-tailed) lebih besar dari nilai alpha 0,05.

Tabel 6.

Hasil Uji Normalitas Struktur 2

\begin{tabular}{lc}
\hline & Unstandardized Residual \\
\hline $\mathrm{N}$ & 130 \\
Kolmogorov-Smirnov $Z$ & 0,669 \\
Asymp.Sig.(2-tailed) & 0,762 \\
\hline Sumber: Data diolah, 2018 &
\end{tabular}

Berdasarkan Tabel 6. dapat dilihat bahwa nilai Kolmogorov Sminarnov (KS) sebesar 0,669, sedangkan nilai Asymp. Sig. (2-tailed) sebesar 0,762. Hasil tersebut mengindikasikan bahwa model persamaan regresi tersebut berdistribusi normal karena nilai Asymp. Sig. (2-tailed) lebih besar dari nilai alpha 0,05.

Adanya multikolinearitas dapat dilihat dari nilai tolerance atau variance inflation factor (VIF). Jika nilai tolerance lebih dari 10 persen atau VIF Kurang dari 10, maka dikatakan tidak ada multikolinearitas.

Tabel 7.

Hasil Uji Multikoleniaritas

\begin{tabular}{lccc}
\hline \multicolumn{1}{c}{ Persamaan Struktur } & Variabel & Tolerance & VIF \\
\hline $\mathrm{Y}_{1}=\beta_{1} \mathrm{X}+\mathrm{e}_{1}$ & Product knowledge $(\mathrm{X})$ & 1,000 & 1,000 \\
$\mathrm{Y}_{2}=\beta_{2} \mathrm{X}+\beta_{3} \mathrm{Y}_{1}+\mathrm{e}_{2}$ & Product knowledge $(\mathrm{X})$ & 0,665 & 1,504 \\
& Positive emotion $\left(\mathrm{Y}_{1}\right)$ & 0,665 & 1,504 \\
\hline
\end{tabular}

Sumber : Data diolah, 2018

Berdasarkan Tabel 7. menunjukkan bahwa variabel product knowledge, dan positive emotion pada persamaan regresi struktur 1 dan 2 memiliki nilai tolerance 
lebih besar dari 10 persen dan nilai VIF lebih kecil dari 10 yang berarti model persamaan regresi bebas dari multikolinearitas.

Jika nilai signifikansinya di atas 0,05 maka tidak mengandung gejala heteroskedastisitas.

Tabel 8.

Hasil Uji Heteroskedastisitas Struktur 1

\begin{tabular}{llccccc}
\hline Model & \multicolumn{5}{c}{$\begin{array}{c}\text { Unstandardized } \\
\text { Coefficients }\end{array}$} & $\begin{array}{c}\text { Standardized } \\
\text { Coefficients }\end{array}$ \\
& & B & Std. Error & Beta & t & Sig. \\
\hline 1 & (Constant) & 0,269 & 0,154 & & 1,748 & 0,083 \\
& Product knowledge & 0,051 & 0,039 & 0,113 & 1,284 & 0,202 \\
\hline
\end{tabular}

Sumber: Data diolah, 2018

Pada Tabel 8. dapat dilihat bahwa nilai signifikansi dari variabel product knowledge sebesar 0,202. Nilai tersebut lebih besar dari 0,05 yang berarti tidak terdapat pengaruh antara variabel bebas terhadap absolute residual. Dengan demikian, model yang dibuat tidak mengandung gejala heteroskedastisitas.

Tabel 9.

Hasil Uji Heteroskedastisitas Struktur 2

\begin{tabular}{llccccc}
\hline Model & \multicolumn{2}{c}{$\begin{array}{c}\text { Unstandardized } \\
\text { Coefficients }\end{array}$} & $\begin{array}{c}\text { Standardized } \\
\text { Coefficients }\end{array}$ & & \\
& & B & Std. Error & Beta & t & Sig. \\
\hline 1 & (Constant) & 0,418 & 0,168 & & 2,490 & 0,014 \\
& Product knowledge & $-0,066$ & 0,045 & $-0,161$ & $-1,492$ & 0,138 \\
& Positive emotion & 0,074 & 0,050 & 0,160 & 1,491 & 0,138 \\
\hline
\end{tabular}

Sumber : Data diolah, 2018

Pada Tabel 9. dapat dilihat bahwa nilai signifikansi dari variabel product knowledge sebesar 0,138 dan positive emotion sebesar 0,138 . Nilai tersebut lebih besar dari 0,05 yang berarti tidak terdapat pengaruh antara variabel bebas terhadap absolute residual. Dengan demikian, model yang dibuat tidak mengandung gejala heteroskedastisitas.

Perhitungan koefisien path atau analisis jalur dilakukan dengan analisis regresi melalui software SPSS 18.0 for Windows, diperoleh hasil yang ditunjukan pada Tabel 10. berikut:

Tabel 10.

Hasil Analisis Jalur 1

\begin{tabular}{lcccc}
\hline \multicolumn{1}{c}{ Variabel } & Standardized Coefficients & Std. Error & t hitung & Sig. uji t \\
\hline (Constant) & 1,806 & 0,253 & 7,153 & 0,000 \\
Product knowledge (X) & 0,579 & 0,065 & 8,029 & 0,000 \\
R Square & 0,335 & & & \\
F Statistik & 64,463 & & & \\
Signifikansi Uji F & 0,000 & & \\
\hline Sumber:
\end{tabular}

Sumber: Data diolah, 2018 
Berdasarkan hasil analisis jalur substruktur 1 seperti yang disajikan pada Tabel 10, maka dapat dibuat persamaan struktural sebagai berikut :

$$
\mathrm{Y}_{1}=0,579 \mathrm{X}
$$

Nilai koefisien regresi variabel product knowledge bernilai positif dengan nilai signifikansi uji t kurang dari 0,05. Hal ini menunjukkan bahwa variabel product knowledge memiliki pengaruh positif yang signifikan terhadap variabel positive emotion. Besarnya pengaruh variabel bebas terhadap variabel terikat yang ditunjukkan oleh nilai determinasi total (R Square) sebesar 0,335 mempunyai arti bahwa sebesar 33,5\% variasi positive emotion dipengaruhi oleh variasi product knowledge, sedangkan sisanya sebesar $66,5 \%$ dijelaskan oleh faktor lain yang tidak dimasukkan ke dalam model.

Tabel 11.

Hasil Analisis Jalur 2

\begin{tabular}{lcccc}
\hline \multicolumn{1}{c}{ Variabel } & Standardized Coefficients & Std. Error & t hitung & Sig. uji t \\
\hline (Constant) & 0,567 & 0,290 & 1,954 & 0,053 \\
Product knowledge (X) & 0,271 & 0,077 & 3,256 & 0,001 \\
Positive emotion (Y) & 0,448 & 0,086 & 5,379 & 0,000 \\
R Square & 0,415 & & & \\
F Statistik & 44,966 & & & \\
Signifikansi Uji F & 0,000 & & & \\
\hline
\end{tabular}

Sumber: Data diolah, 2018

Berdasarkan hasil analisis jalur substruktur 2 seperti yang disajikan pada Tabel 11, maka dapat dibuat persamaan struktural sebagai berikut :

$$
\mathrm{Y}_{2}=0,271 \mathrm{X}+0,448 \mathrm{Y}_{1}
$$

Nilai koefisien regresi masing-masing variabel bebas bernilai positif dengan nilai signifikansi uji t kurang dari 0,050 . Hal ini menunjukkan bahwa semua variabel bebas memiliki pengaruh positif yang signifikan terhadap variabel terikat. Besarnya pengaruh variabel bebas terhadap variabel terikat yang ditunjukkan oleh nilai determinasi total ( $\mathrm{R}$ Square) sebesar 0,415 mempunyai arti bahwa sebesar 41,5 persen variasi Impulse buying dipengaruhi oleh variasi product knowledge dan positive emotion, sedangkan sisanya sebesar 58,50 persen dijelaskan oleh faktor lain yang tidak dimasukkan ke dalam model.

Berdasarkan model substruktur 1 dan substruktur 2, maka dapat disusun model diagram jalur akhir. Sebelum menyusun model diagram jalur akhir, terlebih dahulu dihitung nilai standar eror sebagai berikut :

$$
\begin{aligned}
& P e_{i}=\sqrt{1-R_{i}^{2}} \\
& \mathrm{Pe}_{1}=\sqrt{1-R_{1}{ }^{2}}=\sqrt{1-0,335}=0,815 \\
& \mathrm{Pe}_{2}=\sqrt{1-R_{2}{ }^{2}}=\sqrt{1-0,415}=0,765
\end{aligned}
$$

Berdasarkan perhitungan pengaruh error (Pei), didapatkan hasil pengaruh error $\left(\mathrm{Pe}_{1}\right)$ sebesar 0,815 dan pengaruh error $\left(\mathrm{Pe}_{2}\right)$ sebesar 0,765. Hasil koefisien determinasi total adalah sebagai berikut :

$$
\begin{aligned}
\mathrm{R}^{2}{ }_{\mathrm{m}} & =1-\left(\mathrm{Pe}_{1}\right)^{2}\left(\mathrm{Pe}_{2}\right)^{2} \\
& =1-(0,815)^{2}(0,765)^{2}
\end{aligned}
$$




$$
\begin{aligned}
& =1-(0,664)(0,585) \\
& =1-0,388=0,612
\end{aligned}
$$

Nilai determinasi total sebesar 0,612 mempunyai arti bahwa sebesar $61,2 \%$ variasi Impulse buying konsumen pada produk Zara di Kota Denpasar dipengaruhi oleh variasi product knowledge dan positive emotion, sedangkan sisanya sebesar $38,8 \%$ djelaskan oleh faktor lain yang tidak dimasukkan ke dalam model. berikut.

Perhitungan pengaruh antar variabel dirangkum dalam Tabel 12 sebagai

Tabel 12.

Pengaruh Langsung dan Pengaruh Tidak Langsung serta Pengaruh Total Variabel Penelitian

\begin{tabular}{cccc}
\hline $\begin{array}{c}\text { Pengaruh } \\
\text { Variabel }\end{array}$ & $\begin{array}{c}\text { Pengaruh } \\
\text { Langsung }\end{array}$ & $\begin{array}{c}\text { Pengaruh Tidak Langsung Melalui } \\
\text { Positive emotion } \\
\text { (Y1) }(\boldsymbol{\beta} 1 \text { x } \boldsymbol{\beta 3})\end{array}$ & Pengaruh Total \\
\hline $\mathrm{X} \rightarrow$ Y1 & 0,579 & - & 0,579 \\
$\mathrm{X} \rightarrow \mathrm{Y} 2$ & 0,271 & 0,250 & 0,521 \\
$\mathrm{Y} 1 \rightarrow \mathrm{Y} 2$ & 0,448 & - & 0,448 \\
\hline Sumber : Data diolah 2018 &
\end{tabular}

Tabel 12. menunjukkan bahwa pengaruh langsung product knowledge terhadap positive emotion adalah sebesar 0,579. Pengaruh langsung variabel product knowledge terhadap impulse buying sebesar 0,271. Pengaruh langsung variabel positive emotion terhadap impulse buying sebesar 0,448. Hal ini berarti bahwa variabel impulse buying lebih besar dipengaruhi oleh positive emotion daripada product knowledge. Sedangkan pengaruh tidak langsung variabel product knowledge terhadap impulse buying melalui positive emotion konsumen sebesar 0,250. Jadi pengaruh total variabel product knowledge terhadap impulse buying melalui positive emotion adalah sebesar 0,521. Jadi dapat disimpulkan bahwa lebih besar total pengaruh product knowledge terhadap impulse buying yang melalui positive emotion, daripada pengaruh langsung product knowledge terhadap impulse buying tanpa melalui variabel positive emotion.

Untuk menguji signifikansi pengaruh tidak langsung maka nilai $\mathrm{z}$ dari koefisien ab dihitung dengan rumus sebagai berikut :

$$
\begin{aligned}
& S_{a b}=\sqrt{(0,448)^{2}(0,065)^{2}+(0,579)^{2}(0,086)^{2}+(0,065)^{2}(0,086)^{2}} \\
& S_{a b}=0,07446
\end{aligned}
$$

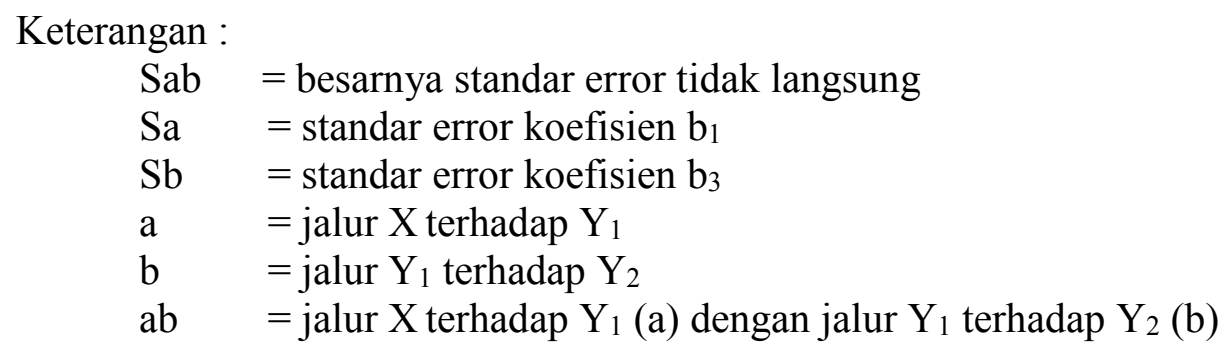

Untuk menguji signifikansi pengaruh tidak langsung maka menghitung nilai $\mathrm{z}$ dari koefisien $\mathrm{ab}$ dengan rumus sebagai berikut : 


$$
\begin{aligned}
& Z=\frac{a b}{S a b} \ldots \ldots \ldots \ldots \ldots \ldots \ldots \ldots \ldots \ldots \ldots \ldots \ldots \ldots \ldots \\
& Z=\frac{(0,579)(0,448)}{0,057954} \\
& Z=4,4758 \text { dengan signifikansi } 0,000
\end{aligned}
$$

Oleh karena $Z$ hitung sebesar 4,4758 > 1,96. Artinya Positive emotion (Y1) merupakan variabel yang memediasi product knowledge (X) terhadap impulse buying (Y2) konsumen pada produk Zara di Kota Denpasar atau dengan kata lain product knowledge berpengaruh secara tidak langsung terhadap impulse buying melalui positive emotion.

Hasil analisis menunjukkan bahwa product knowledge berpengaruh positif dan signifikan terhadap positive emotion. Hal ini memiliki makna bahwa semakin tinggi pengetahuan konsumen pada produk Zara, maka semakin tinggi pula positive emotion yang akan terbentuk pada konsumen. Begitu pula sebaliknya, semakin rendah pengetahuan konsumen pada produk Zara, maka semakin rendah pula positive emotion yang akan terbentuk pada konsumen.

Penelitian ini mendukung beberapa hasil penelitian sebelumnya dan konsisten dengan hasil penelitian (Suwandi \& Soelasih, 2014), serta (Hodgins \& Dadich, 2017) yang mendapatkan hasil bahwa product knowledge berpengaruh positif dan signifikan terhadap emosi positif. Penelitian tersebut menjelaskan bahwa semakin tinggi tingkat pengetahuan produk konsumen maka akan menyebabkan positive emotion konsumen semakin meningkat. Hasil penelitian ini juga didukung oleh penelitian yang dilakukan oleh (Suwandi \& Soelasih, 2014) yang menyatakan bahwa adanya pengaruh yang signifikan antara pengetahuan konsumen terhadap emosi positif.

Hasil analisis menunjukkan bahwa product knowledge berpengaruh positif dan signifikan terhadap impulse buying. Hal ini memiliki makna bahwa semakin tinggi product knowledge yang dimiliki konsumen pada produk Zara, maka konsumen akan lebih mengenal kualitas produk tersebut, sehingga akan mampu mendorong perilaku pembelian tidak terencana yang dilakukan oleh konsumen.

Penelitian ini mendukung beberapa hasil penelitian sebelumnya dan konsisten dengan hasil penelitian (Juanita, 2010), (Liang, 2012) dan (Deviana \& Giantari, 2016) yang memperoleh hasil bahwa pengaruh yang signifikan dan positif antara pengetahuan produk terhadap impulse buying, artinya perilaku pembelian tidak terencana akan semakin meningkat apabila konsumen memiliki pengetahuan produk yang baik.

Hasil analisis dalam penelitian ini menunjukkan bahwa positive emotion berpengaruh positif dan signifikan terhadap impulse buying. Hal ini memiliki makna bahwa semakin positif perasaan konsumen saat melakukan interaksi di dalam gerai Zara Beachwalk, maka kecenderungan konsumen untuk melakukan pembelian impulsif juga semakin besar. Begitu pula sebaliknya, semakin buruk perasaan konsumen saat melakukan interaksi di dalam gerai Zara Beachwalk, maka kecenderungan konsumen untuk melakukan pembelian impulsif juga semakin berkurang.

Penelitian ini konsisten dengan hasil penelitian (Park \& Lennon, 2006) dan $(\mathrm{Xu}, 2007)$ yang menyatakan bahwa semakin positif luapan perasaan yang dirasa konsumen akan mendorong konsumen untuk melakukan tindakan impulsif. 
Penelitian ini mendukung beberapa hasil penelitian sebelumnya oleh (Anggoro, 2013), (Naentiana \& Setiawan, 2014), (Adiputra, 2015) dan (Budiharta \& Santika, 2015) yang mendapatkan hasil bahwa emosi positif berpengaruh positif dan signifikan terhadap pembelian impulsif.

Berdasarkan hasil uji Sobel, ditemukan pengaruh yang positif antara variabel product knowledge terhadap impulse buying melalui variabel positive emotion. Hasil penelitian ini konsisten dengan hasil penelitian yang dilakukan oleh (Anggoro, 2013) yang menemukan bahwa emosi positif berpengaruh positif dan signifikan terhadap pembelian impulsif, yang artinya bahwa semakin positif perasaan konsumen saat melakukan interaksi di dalam gerai, maka kecenderungan konsumen untuk melakukan pembelian impulsif juga semakin besar. Jika Zara mampu memberikan product knowledge yang tinggi bagi konsumen, maka product knowledge tersebut akan mampu meningkatkan positive emotion konsumen dan pada akhirnya impulse buying konsumen pada produk Zara akan semakin meningkat.

Konsumen yang sudah memiliki pengetahuan produk yang baik mengenai Zara collection, tentu akan mengetahui kualitas produk tersebut sehingga akan dapat mendorong timbulnya perasaan positif konsumen, dan pada akhirnya akan mampu meningkatkan perilaku pembelian tidak terencana konsumen pada produk Zara. Maka dapat disimpulkan bahwa positive emotion dapat memediasi product knowledge terhadap impulse buying konsumen. Penelitian juga didukung oleh (Juanita, 2010), (Naentiana \& Setiawan, 2014), serta (Hodgins \& Dadich, 2017) yang memperoleh hasil bahwa terdapat pengaruh yang signifikan dari variabel product knowledge terhadap impulse buying melalui variabel positive emotion. Positive emotion secara positif dan signifikan memediasi pengaruh product knowledge terhadap impulse buying konsumen, memiliki makna bahwa product knowledge yang sudah dimiliki konsumen terhadap produk Zara mampu meningkatkan impulse buying konsumen secara langsung dan tidak langsung melalui positive emotion tersebut. Pengaruh total variabel product knowledge terhadap impulse buying melalui positive emotion adalah sebesar 0,521. Jadi dapat disimpulkan bahwa lebih besar total pengaruh product knowledge terhadap impulse buying yang melalui positive emotion. Hal ini disebabkan karena konsumen cenderung lebih bersemangat, lebih puas, sangat senang dan merasa penuh dengan emosi saat berbelanja produk Zara di Beachwalk walaupun konsumen tidak terlalu memiliki banyak pengetahuan produk Zara.

\section{SIMPULAN}

Product knowledge berpengaruh positif dan signfikan terhadap positive emotion konsumen pada produk Zara, yaitu semakin tinggi pengetahuan konsumen pada produk Zara, maka semakin tinggi pula positive emotion yang akan terbentuk pada konsumen. Product knowledge berpengaruh positif dan signfikan terhadap impulse buying konsumen pada produk Zara, yaitu semakin tinggi product knowledge yang dimiliki konsumen pada produk Zara, maka konsumen akan lebih mengenal kualitas produk tersebut, sehingga akan mampu mendorong perilaku pembelian tidak terencana yang dilakukan oleh konsumen. 
Positive emotion berpengaruh positif dan signifikan terhadap impulse buying konsumen pada produk Zara yaitu semakin positif perasaan konsumen saat melakukan interaksi di dalam gerai Zara Beachwalk, maka kecenderungan konsumen untuk melakukan pembelian impulsif juga semakin besar. Positive emotion secara positif dan signifikan memediasi pengaruh product knowledge terhadap impulse buying konsumen pada produk Zara, yaitu Konsumen yang sudah memiliki pengetahuan produk yang baik mengenai Zara collection, tentu akan mengetahui kualitas produk tersebut sehingga akan dapat mendorong timbulnya perasaan positif konsumen, dan pada akhirnya akan mampu meningkatkan perilaku pembelian tidak terencana konsumen pada produk Zara.

Hasil penyebaran kuisioner menunjukkan bahwa indikator yang memperoleh penilaian terkecil pada variabel impulse buying adalah indikator pembelian pakaian model terbaru dan indikator terobsesi untuk membelanjakan seluruh uang. Hal ini menunjukkan bahwa tidak semua konsumen selalu membeli pakaian model terbaru yang di tawarkan Zara dan terobsesi untuk membelanjakan seluruh uang yang dimiliki untuk membeli produk Zara. Oleh karena itu, dalam upaya meningkatkan impulse buying konsumen pada produk Zara, maka pihak manajemen Zara sebaiknya menyediakan promosi dan diskon menarik saat peluncur model produk Zara terbaru, sehingga dengan adanya diskon dan promosi merchadise yang menarik dapat mempengaruhi konsumen untuk membelanjakan seluruh uang yang dimiliki untuk membeli produk Zara, sehingga perilaku pembelian tidak terencana akan semakin meningkat.

Hasil dari penelitian ini diharapkan mampu mendorong peneliti-peneliti selanjutnya untuk mengamati faktor-faktor lain yang dapat mempengaruhi impulse buying konsumen selain product knowledge dan positive emotion. Penelitian selanjutnya juga diharapkan dapat menambah jumlah sampel penelitian serta memperluas wilayah sampel peneliti, sehingga nanti hasilnya dapat digeneralisasikan untuk lingkup yang lebih luas.

\section{REFERENSI}

Adiputra, E. (2015). Perilaku Pembelian Tidak Terencana (Impulse Buying) di Pusat Perbenjaan Modern di Surabaya. An-Nisbah: Jurnal Ekonomi Syariah, 1(2), 155-180.

Amiri, F., Jasour, J., Shirpour, M., \& Alizadeh, T. (2012). Evaluation of Effective Fashionism Involvement Factors Effects on Impulse Buying of Customers and Condition of Interrelation between These Factors. Journal of Basic and Applied Scientific Reseacrh, 2(9), 9413-9419.

Anggoro, S. P. (2013). Analisis Pengaruh Store Atmosphere terhadap Impulse Buying melalui Emotional Response di Matahari Department Store Tunjungan Plaza Surabaya. Jurnal Ilmiah Mahasiswa Manajemen, 1(2), 1-5.

Broden, A., \& Soderberg, C. (2011). Impulse Buying, Reasons Why and 
Consumer Electronics, Oh My! University of Gothenburg.

Budiharta, K., \& Santika, I. W. (2015). Peran Emosi Positif sebagai Pemediasi Pengaruh Stimulus Toko terhadap Impulse Buying Pakaian di Matahari Department Store Kuta Square. E-Jurnal Manajemen Universitas Udayana, $4(3), 457-473$.

Deviana, N. P. S., \& Giantari, I. G. A. K. (2016). Pengaruh Shopping Lifestyle dan Fashion Involvement terhadap Impulse Buying Behavior Masyrakat di Kota Denpasar. E-Jurnal Manajemen Universitas Udayana, 5(8), 52645273.

Han, H., Hsu, L.-T. J., \& Sheu, C. (2010). Application of the Theory of Planned Behavior to Green Hotel Choice: Testing the Effect of Environmental Friendly Activities. Tourism Management Journal, 31, 325-334.

Hodgins, M., \& Dadich, A. (2017). Positive Emotion in Knowledge Creation. Journal of Health Organization and Management, 31(2), 162-174.

Japarianto, E., \& Sugiharto, S. (2011). Pengaruh Shopping Life Style dan Fashion Involvement terhadap Impulse Buying Behavior Masyarakat High Income Surabaya. Jurnal Manajemen Pemasaran, 6(1), 32-41.

Kurniawan, D., \& Kunto, Y. S. (2013). Pengaruh Promosi dan Store Atmosphere terhadap Impulse Buying dengan Shopping Emotion sebagai Variabel Intervening Studi Kasus di Matahari Department Store Cabang Supermall Surabaya. Jurnal Manajemen Pemasaran Petra, 1(2), 1-8.

Liang, Y. (2012). The Relationship Between Consumer Product Involvement, Product Knowledge and Impulsive Buying Behavior. Procedia-Social and Behavioral Sciences, 57, 325-330.

Naentiana, P. V., \& Setiawan, P. Y. (2014). Peran Positive Emotion dalam Memediasi Pengaruh Hedonic Shopping Value terhadap Impulse Buying (Studi Kasus: Mall Bali Galeria). E-Jurnal Manajemen Universitas Udayana, 3(8), 2314-2332.

Park, J., \& Lennon, S. J. (2006). Psychological and Environmental Antecedents of Impulse Buying Tendency in the Multichannel Shopping Context. Journal of Consumer Marketing, 23(2), 56-66.

Rachmawati, V. (2009). Hubungan antara Hedonic Shopping Value, Positive Emotion, dan Perilaku Impulse Buying pada Konsumen Ritel. Jurnal Ekonomi Dan Bisnis Airlangga, 19(2), 192-209.

Ridwan, L. M., Solihat, A., \& Trijumansyah, A. (2018). Pengaruh Product 
E-Jurnal Manajemen, Vol. 8, No. 9, 2019 :5652-5671

Knowledge dan Brand Association Terhadap Purchase Intention Kawasan Kampung Kreatif Dago Pojok. Jurnal Pariwisata, 5(1), 68-82.

Suwandi, F. M., \& Soelasih, Y. (2014). Analisis Pengaruh Lingkungan Toko dan Pengetahuan Produk Terhadap Perilaku Pembelian Impulsif dengan Emosi Positif sebagai Mediator pada Kosmetik Impor di Indonesia. Portofolio, 11(1), 36-47.

$\mathrm{Xu}, \mathrm{Y}$. (2007). Impact of Store Environment on Adult Generation Y Consumers' Impulse Buying. Journal of Shopping Center Research, 14(1), 39-56. 